\title{
Papers
}

\section{Detection of telomerase in hepatocellular carcinomas using a PCR ELISA assay: comparison with hTR expression}

\author{
Sophie Ferlicot, Valérie Paradis, Delphine Dargère, Geneviève Monges, Pierre Bedossa
}

\begin{abstract}
Background-While telomerase is undetectable in most normal somatic tissues, telomerase activation has been detected in many immortal cell lines and various cancers.

Aim-To investigate telomerase expression in hepatocellular carcinoma, and to assess the expression of the RNA component of telomerase, hTR.

Methods-39 hepatocellular carcinomas were studied using a telomerase polymerase chain reaction (PCR) enzyme linked immunosorbent assay, which does not require radioactive $P C R$ amplification and yields a semiquantitative measurement. Expression of hTR was also assessed by a non-radioactive in situ hybridisation procedure. The correlations between these two markers and the clinicopathological data were analysed.

Results-Telomerase activity was detected in 23 of 39 hepatocellular carcinoma specimens $(59 \%)$. Comparison of hepatocellular carcinoma with and without telomerase expression, or with high and low telomerase (10 cases $v 13$ cases), showed no differences in the principal clinicopathological data. Although median survival was lower in the group with detectable telomerase activity than in that with undetectable activity (510 $v 720$ days) the difference was not significant (logrank test, $p=0.08)$. hTR expression was detected in 11 of 14 cases of hepatocellular carcinoma tested $(78 \%)$ and in four of 12 samples of adjacent non-cancerous tissue $(33 \%)$. Five tumours and four noncancerous tissues were positive for hTR, whereas no telomerase activity was detected in these.

Conclusions-The presence of telomerase activity in hepatocellular carcinomas is confirmed. No correlation was observed between clinicopathological data and telomerase expression in hepatocellular carcinoma, but survival seemed better in the absence of telomerase expression. hTR seems to be more widely expressed than telomerase.

(f Clin Pathol 1999;52:725-729)
\end{abstract}

Keywords: hepatocellular carcinoma; telomerase; hTR; cirrhosis

Telomeres are non-coding repetitive DNA sequences (TTAGGG), localised at the end of all chromosomes. ${ }^{1}$ They are of importance in stabilising and protecting the chromosomal ends during replication. ${ }^{12}$ Furthermore, telomere length has been proposed as a major mechanism in regulating the life span of normal somatic cells. Indeed, telomeric repeats are lost with each cell division, since DNA polymerase cannot replicate the very end of a linear DNA molecule. ${ }^{3}$ In vitro, after repeated cell divisions cells with telomeres that are too short stop dividing, become unstable, and enter into senescence. This "end replication" problem can be overcome in certain circumstances by telomerase, a DNA polymerase that catalyses the addition of new TTAGGG repeats at chromosome ends in eukaryotic cells. ${ }^{4}$ Significant levels of telomerase have been detected in germ line cells and immortal cells, but not in most somatic cells.

A highly sensitive polymerase chain reaction (PCR) based telomerase assay, the TRAP assay (telomeric repeat amplification protocol) has been developed for the detection of telomerase activity. ${ }^{5}$ Using this technique, studies have confirmed that telomerase activity is undetectable in most normal somatic human tissues, except for stem cells, whereas it is present in most primary human cancers and tumour derived cell lines. ${ }^{5}$ Therefore, de novo telomerase expression has been considered to be one of the key mechanisms in cell immortalisation, and telomerase may be regarded as a marker of malignancy and a new target in cancer treatment.

Telomerase is a ribonucleoprotein DNA polymerase composed of a protein component with catalytic activity (hTERT) and an RNA component (hTR) for use as a template in DNA replication. In 1995, Feng et al cloned the gene coding for hTR, enabling the further development of molecular probes for in situ hybridisation. ${ }^{67}$ More recently, hTERT has also been cloned. ${ }^{8}$ Although the detailed mechanism resulting in de novo telomerase expression is unknown, strong experimental 
evidence suggests that both hTR and hTERT expression are needed for telomerase to be enzymatically active. Indeed, mouse germ cells without telomerase RNA (mTR) lack detectable telomerase activity. ${ }^{9}$ Similarly, telomerase activity can be restored in telomerase negative cells by inducing the expression of hTERT. ${ }^{10}$

Hepatocellular carcinoma is the most common primary hepatic malignancy. Despite some progress in its early diagnosis and clinical management, the prognosis of hepatocellular carcinoma remains very poor. Up to now, there have been few studies reporting telomerase activity in chronic liver diseases and hepatocellular carcinoma and, as far as we know, no report has studied the expression of hTR in hepatocellular carcinomas. ${ }^{11-14}$

Our aim in this study was to determine telomerase status in a series of hepatocellular carcinomas using a telomerase PCR enzyme linked immunosorbent assay (ELISA), an assay that does not require radioactive PCR amplification and yields a semiquantitative measurement. Furthermore, hTR expression was also assessed on the same samples by a nonradioactive in situ hybridisation procedure. Finally, correlations between these two markers and the clinicopathological data were analysed.

\section{Methods}

PATIENTS

Thirty nine specimens of hepatocellular carcinoma were obtained by surgical resection. In 35 cases, non-cancerous tissue adjacent to the carcinomas was also available. All samples were immediately frozen in liquid nitrogen and stored at $-80^{\circ} \mathrm{C}$ until use. Complementary OCT (Tissue-Tek) embedded frozen tissue was also available in 26 cases and was used for in situ hybridisation. Specimens from tumoral and non-tumoral tissue were also routinely processed, formalin fixed, and paraffin embedded for histological examination.

For each hepatocellular carcinoma, the following clinicopathological criteria were evaluated: age, sex, size of the tumour, hepatocellular carcinoma grading, extension beyond the capsule, vascular invasion, concomitant liver cirrhosis, and the presence of satellite nodules.

DETECTION OF TELOMERASE ACTIVITY

Telomerase activity was measured by a modified version of the standard TRAP method, the telomerase PCR ELISA kit, according to the manufacturer's instructions (Boehringer Mannheim). This assay allows specific PCR amplification of telomerase mediated elongation products combined with non-radioactive detection and semiquantification of the amplification products with an ELISA procedure.

Twelve frozen sections $(10 \mu \mathrm{m})$ of each sample were homogenised in $200 \mu$ of ice cold lysis buffer and incubated for 30 minutes on ice. After centrifugation at $16000 \mathrm{~g}$ for 20 minutes at $4^{\circ} \mathrm{C}$, the supernatant was collected, quickly frozen in liquid nitrogen, and stored at $-80^{\circ} \mathrm{C}$. Protein concentration was measured by use of the DC protein assay kit (Bio-Rad Laborato- ries). Tissue extract was incubated with reaction buffer including a biotin labelled P1-TS primer and P2 primer, telomerase substrate, and Taq polymerase for 30 minutes at $25^{\circ} \mathrm{C}$ in a final volume of $50 \mu \mathrm{l}$. After further incubation at $94^{\circ} \mathrm{C}$ for five minutes, the resulting mixture was subjected to the PCR for 30 cycles of 30 seconds at $94^{\circ} \mathrm{C}, 30$ seconds at $50^{\circ} \mathrm{C}$, and 90 seconds at $72^{\circ} \mathrm{C}$.

The amplification products were denatured and hybridised with a digoxigenin labelled, telomeric repeat specific detection probe. The resulting product was immobilised through the biotin labelled TS primer to a streptavidin coated microtitre plate and detected with an antidigoxigenin antibody conjugated with peroxidase. Absorbance values were measured using a microtitre reader at $450 \mathrm{~nm}$ with a reference wavelength of $690 \mathrm{~nm}$. Samples were regarded as telomerase positive if the difference in absorbance was higher than 0.2 arbitrary units $\left(\mathrm{A}_{450 \mathrm{~nm}}-\mathrm{A}_{690 \mathrm{~nm}}\right)$. The absorbance reading obtained with the positive control supplied with the kit was always higher than $1.5 \mathrm{U}$. All extracts were initially tested at $1 \mu \mathrm{g} / \mu \mathrm{l}$ of protein. In cases where telomerase activity was undetectable at this concentration, extracts were also tested at various concentrations ranging from 0.02 to $6 \mu \mathrm{g} / \mu \mathrm{l}$ of protein. All assays were performed in duplicate.

IN SITU HYBRIDISATION FOR hTR

The riboprobe was generated from a 168 base pair (bp) complementary DNA by PCR using the following primers: 5'CCGCCTTCCACCGTTCATTC3' and 5'CAACTCTTCGCGGTGGCAGT3'. Sense and antisense probes were synthesised from linearised pTAdv plasmid by in vitro transcription with T7 polymerase and labelled with digoxigenin-UTP.

Aliquots of the probes were stored at $-20^{\circ} \mathrm{C}$ until use. For each case, frozen sections $(5 \mu \mathrm{m})$ were cut onto ProbeOn Plus glass slides (Fischer Biotech). The sections were rinsed with $1 \times$ phosphate buffered saline (PBS) and prehybridised for one hour at $42^{\circ} \mathrm{C}$ in hybridisation buffer ( $4 \times \mathrm{SSC}(\mathrm{NaCl} /$ sodium citrate), $10 \%$ dextran sulphate, $1 \times$ Denhart solution, 2 $\mathrm{mM}$ EDTA, $50 \%$ formamide, $500 \mu \mathrm{g} / \mathrm{ml}$ salmon sperm DNA). Hybridisation was performed at $42^{\circ} \mathrm{C}$ overnight in the hybridisation buffer containing $800 \mathrm{ng} / \mathrm{ml}$ of the digoxigenin labelled probe. The section was washed at $42^{\circ} \mathrm{C}$ in $2 \times \mathrm{SSC}$ for five minutes, at $42^{\circ} \mathrm{C}$ in $50 \%$ formamide $/ 0.2 \times$ SSC for five minutes, and at $42^{\circ} \mathrm{C}$ in $0.2 \times \mathrm{SSC}$ for five minutes. Following washes in $0.1 \times$ SSC for five minutes at room temperature, the slides were rinsed in buffer 1 (100 mM Tris- $\mathrm{HCl}, 150 \mathrm{mM} \mathrm{NaCl}$, $\mathrm{pH} \mathrm{7.5)} \mathrm{for} \mathrm{five} \mathrm{minutes} \mathrm{at} \mathrm{room} \mathrm{temperature,}$ and blocked for 30 minutes. Slides were then incubated with antidigoxigenin antibody (1/ 200) for two hours at room temperature. After two rinses in buffer 1 , slides were rinsed in buffer 3 (100 mM Tris- $\mathrm{HCl}, 100 \mathrm{mM} \mathrm{NaCl}$, $50 \mathrm{mM} \mathrm{MgCl}$, $\mathrm{pH}$ 9.5) for 10 minutes. Alkaline phosphatase was detected using 5-bromo 4-chloro 3-indolyl phosphate and nitroblue 
tetrazolium chloride. Slides were then rinsed in buffer 4 (10 mM Tris-HCl, $1 \mathrm{mM}$ EDTA, $\mathrm{pH} 8$ ).

A liver tissue metastasis with known strong telomerase activity by the TRAP method was used as a positive control. Hybridisation with a sense probe served as the negative control.

\section{STATISTICAL ANALYSIS}

The correlations between qualitative data were studied with the $\chi^{2}$ and Fischer tests. A probability $(\mathrm{p})$ value $<0.05$ was considered statistically significant. Life tables were estimated by Kaplan-Meier statistics, and survival curves were compared using the log-rank test.

\section{Results}

PATIENTS

The study included 39 patients. They were 34 men and five women with a mean age of 62 years (range 34 to 78 ). The mean (SD) tumour diameter was 5.9 (3.5) $\mathrm{cm}$ (range 2 to 14). According to the Edmonson classification, tumours were graded 1 in 11 cases, 2 in 22 cases, and 3 in six cases. Satellite nodules, capsular effraction, and vascular invasion were observed in $67 \%, 79 \%$, and $38 \%$ of cases, respectively. Twenty seven of the 39 patients had concomitant liver cirrhosis, whereas the remainder had fibrosis.

\section{QUANTITATIVE DETECTION OF TELOMERASE ACTIVITY}

Telomerase activity was greater than $0.2 \mathrm{U}$ in 23 of 39 hepatocellular carcinoma specimens $(59 \%)$ and in one of 35 non-tumoral liver tissue specimens surrounding the tumour (3\%). In 10 hepatocellular carcinomas, the telomerase value was higher than $1 \mathrm{U}$. When comparing hepatocellular carcinomas with detectable and undetectable telomerase activity, no differences were observed in the principal clinicopathological data. Among the cases with detectable activity, there was also no difference when carcinomas with high and low telomerase activity were compared. Detailed data are reported in table 1 .

A PCR inhibitor was assumed to have been present in four of the 23 positive cases, because

Table 1 Clinicopathological data in hepatocellular carcinoma according to telomerase expression

\begin{tabular}{|c|c|c|c|}
\hline & $\begin{array}{l}\text { Cases without detectable } \\
\text { telomerase expression }(n=16)\end{array}$ & $\begin{array}{l}\text { Cases with detectable } \\
\text { telomerase expression }(n=23)\end{array}$ & $p$ Value \\
\hline Age (years, mean (SD)) & $65(11)$ & $59(9)$ & NS \\
\hline $\operatorname{Sex}(n)$ & & & NS \\
\hline Female & $2(12 \%)$ & $3(12 \%)$ & \\
\hline Male & $14(88 \%)$ & $20(88 \%)$ & \\
\hline Tumour size $(\mathrm{cm})$ & $6.3(3.9)$ & $5.6(3.2)$ & NS \\
\hline \multicolumn{3}{|c|}{ Extension through capsule (n) } & NS \\
\hline Absence & $4(27 \%)$ & $4(19 \%)$ & \\
\hline Presence & $12(73 \%)$ & $19(81 \%)$ & \\
\hline \multicolumn{3}{|l|}{ Vascular invasion $(\mathrm{n})$} & NS \\
\hline Absence & $11(67 \%)$ & $13(56 \%)$ & \\
\hline Presence & $5(33 \%)$ & $10(44 \%)$ & \\
\hline \multicolumn{3}{|l|}{ Satellite nodules (n) } & NS \\
\hline Absence & $8(47 \%)$ & $9(38 \%)$ & \\
\hline Presence & $12(53 \%)$ & $14(62 \%)$ & \\
\hline \multicolumn{3}{|l|}{ Grade (n) } & NS \\
\hline 1 and 2 & $15(92 \%)$ & $18(77 \%)$ & \\
\hline 3 and 4 & $1(8 \%)$ & $5(23 \%)$ & \\
\hline \multicolumn{3}{|l|}{ Cirrhosis (n) } & NS \\
\hline Absent & $6(40 \%)$ & $6(28 \%)$ & \\
\hline Present & $10(60 \%)$ & $17(71 \%)$ & \\
\hline Median survival (d) & 720 & 510 & NS $(p=0.08)$ \\
\hline
\end{tabular}

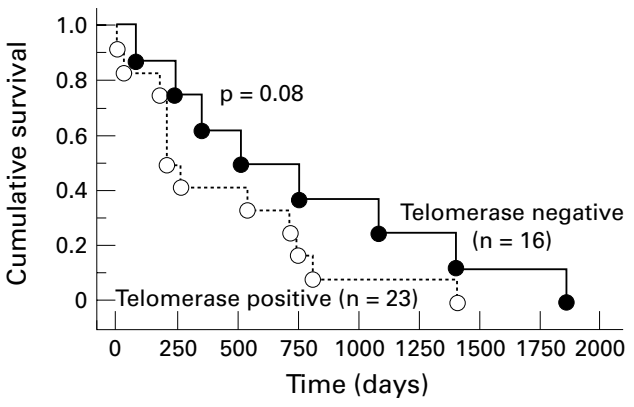

Figure 1 Kaplan-Meier plots of estimated probability of survival according to telomerase expression.

in these samples the assay was initially negative when tested at $1 \mu \mathrm{g} / \mu \mathrm{l}$, but serial dilution of the extract subsequently allowed the detection of telomerase activity.

The $50 \%$ cumulative survival was 510 days in the group with detectable telomerase activity and 720 days in the group with undetectable activity. Although, the cumulative survival rate of the latter group tended to be slightly better than that of the former group, there was no significant difference between the two groups (log-rank test, $\mathrm{p}=0.08$ ) (fig 1 ). The same trend for better survival was observed when cases with detectable but low telomerase level ( $<1 \mathrm{U}, 13$ cases) were compared with cases with high telomerase activity ( $\geqslant 1 \mathrm{U}, 10$ cases) (540 $v 210$ days).

IN SITU HYBRIDISATION

The liver metastasis used as positive control showed strong expression of hTR by tumour cells.

Expression of hTR was detected in 11 of 14 hepatocellular carcinomas tested $(78 \%)$ and in four of 12 samples of adjacent non-cancerous tissue (33\%). Positive tumour cells showed nuclear labelling, sometimes with cytoplasmic diffusion (fig 2). Labelling was patchy in distribution.

In four cases of non-cancerous tissue, positive cells composed of sparse hepatocytes were also detected. In three cases, numerous lymphocytes were observed and some of these were positive.

In no case did slides hybridised with a sense probe show staining.

CORRELATIONS BETWEEN TELOMERASE ACTIVITY AND TELOMERASE RNA COMPONENT (hTR) Twenty six samples (14 tumour samples and 12 non-cancerous samples) were compared using the TRAP assay and hTR in situ hybridisation.

Six of the 26 samples (six tumours) were positive for both hTR expression and telomerase activity. Nine of the 26 samples (five tumours and four non-cancerous tissues) were positive for hTR expression, whereas no telomerase activity was detected.

\section{Discussion}

Telomerase plays a crucial role in carcinogenesis. Indeed, telomerase activity has been detected in a wide variety of cancers, while being undetectable in most normal cells and tissues. ${ }^{5}$ According to these data, telomerase is a potential diagnostic marker in carcinogenesis. 

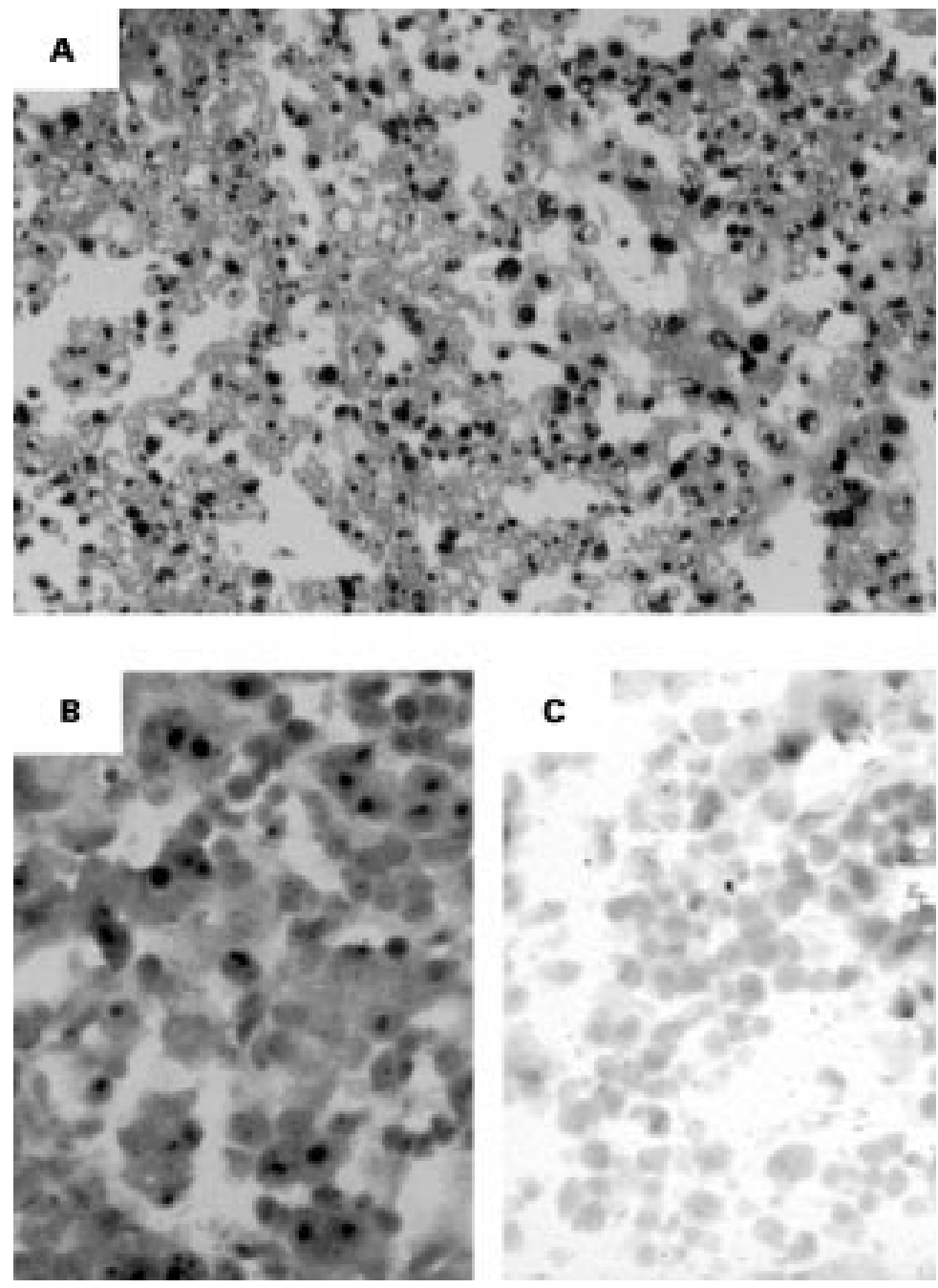

Figure 2 Expression of hTR in hepatocellular carcinoma. (A) In situ hybridisation of a section of a hepatocellular carcinoma with a digoxigenin labelled $h T R R N A$ antisense probe. Most of tumoral cells show strong nuclear labelling (magnification $\times 12)$. (B) Higher magnification of $(A)$ (magnification $\times 30$ ). (C) Hybridisation with a sense probe. No staining is observed (magnification $\times 24$ ).

In the present study, we analysed telomerase status in a series of hepatocellular carcinomas and detected it in $59 \%$ of the cases. This prevalence is lower than in previous reports, where telomerase activity was found in 85$90 \%$ of hepatocellular carcinomas. ${ }^{11-14}$ This discrepancy warrants further discussion. We ruled out the presence of PCR inhibitors in the sample, a frequently mentioned drawback that can lead to false negative results. ${ }^{15-18}$ This was achieved first, by performing the TRAP assay with serial dilutions of the extracts, and second, by performing a complementary TRAP reaction in negative specimens under the same conditions but with the addition of an extract of telomerase positive cells serving as an internal control.

It has recently been suggested that the absence of telomerase activity in carcinomatous tissue could be the result of degraded RNA or protein activity. ${ }^{19}$ Although we cannot definitely rule out this hypothesis as we did not check RNA quality by gel electrophoresis, the detection of the RNA component (hTR) in $78 \%$ of cases strongly suggests the absence of RNA degradation in most cases. Finally, the lower frequency of telomerase detection observed in our study could be related to the lower sensitivity of the non-radioactive procedure that we used. Non-radioactive methods are known to be less sensitive than radioactive methods, though easier to handle. It is clear that in this method, the addition of a supplementary detection step of hexanucleotide repeats with a specific digoxigenin labelled probe has the potential both to increase specificity and to decrease sensitivity.

One of the advantages of this method consists in the quantitative evaluation of telomerase activity. Indeed, we observed varying levels of telomerase activity for the same protein concentration depending on the tumour, and it was tempting to compare clinicopathological data with the telomerase levels. However, owing to the lower sensitivity of the PCR-ELISA assay, those hepatocellular carcinomas with detectable but low telomerase levels would probably have high telomerase activity with the conventional radioactive assay. This might explain why in the telomerase detectable hepatocellular carcinomas no apparent correlation was observed between any of the clinicopathological features and the presence of low or high telomerase activity. The same was true when we compared the data in the carcinomas with and without detectable telomerase. However, a tendency toward better survival was observed in cancers without detectable telomerase expression. Further study of a larger number of patients is needed to draw definitive conclusions.

There is still controversy over whether there is a correlation between telomerase activity and hTR expression. We were able to show that tumour cells of 11 of the 14 hepatocellular carcinoma cases $(78 \%)$ studied by in situ hybridisation expressed hTR. Among these, telomerase was detected in only six cases. Experimental studies have shown that telomerase expression cannot be observed in the absence of hTR; however, hTR expression is not sufficient to ensure that there is telomerase activity. ${ }^{20}$ It is now clear that another component, hTERT - the catalytic protein component of the telomerase complex-is also necessary and might be the limiting step for telomerase activity. ${ }^{21}{ }^{22}$ Further studies on hTERT expression and regulation are clearly needed .

Finally, mechanisms of cellular immortality might not be limited to telomerase activation, since most studies, including ours, have found some malignant tumours without telomerase, and alternative pathways to cellular immortality may exist. ${ }^{23}$

Several studies have shown that telomerase is expressed early in precancerous lesions such as prostatic intraepithelial neoplasia and dysplastic lesions of the urinary tract. ${ }^{182}{ }^{24}$ Fibrosis and cirrhosis in the vicinity of hepatocellular carcinoma can also be considered preneoplastic. Using our technique, we detected telomerase activity in one of 35 cases, and hTR expression in four of 12 samples of non-neoplastic tissues. These results are consistent with those of previous studies and confirm that activation of telo- 
merase may occur early during multistage progression of liver disease. ${ }^{13} 14$

CONCLUSIONS

Our study confirms the presence of telomerase activity in hepatocellular carcinogenesis. The quantitative non-radioactive test seems to be less sensitive than the usual TRAP method, but is easier to perform. No correlation was observed between clinicopathological data and telomerase expression in hepatocellular carcinoma but survival seemed to be better in the absence of telomerase expression. Finally, hTR was more widely expressed than telomerase activity and was not rate limiting for telomerase activity.

This study was supported by grants from Fonds de Recherche de la Société Nationale française de Gastroentérologie, Association pour la Recherche contre le Cancer et Ligue nationale contre le cancer, comité des Hauts-de-Seine.

1 Blackburn EH. Structure and function of telomeres. Nature 1991;350:569-73.

2 Zakian VA. Telomeres: beginning to understand the end. Science 1995;270:1601-7.

3 Levy MZ, Allsopp RC, Futcher AB, et al. Telomere end-replication problem and cell aging. $f \mathrm{Mol}$ Bio 1992;225:951-60.

4 Collins K. Structure and function of telomerase. Curr Opin Cell Biol 1996;8:374-80

5 Kim NW, Piatyszek MA, Prowse KR, et al. Specific association of human telomerase activity with cells and cancer. Science 1994;266:2011-15.

6 Yashima K, Litzky LA, Kaiser L, et al. Telomerase expression in respiratory epithelium during the multistage pathogenesis of lung carcinomas. Cancer Res 1997;57: 2373-7.

7 Feng J, Funk WD, Wang SS, et al. The RNA component of human telomerase. Science 1995;269:1236-40.

8 Nakamura TM, Morin GB, Chapman KB, et al. Telomerase Nakamura TM, Morin GB, Chapman KB, et al. Telomerase catalytic subunit homologs

9 Blasco MA, Lee HW, Hande MP. Telomere shortening and tumor formation by mouse cells lacking telomerase RNA. Cell 1997;91:25-34.
10 Counter CM, Meyerson M, Eaton EN, et al. Telomerase activity is restored in human cells by ectopic expression of hTERT (hEST2), the catalytic subunit of telomerase. Oncogene 1998;16:1217-22.

11 Hisatomi H, Kawaoto Y, Ohmura Y, et al. Detection of telomerase activity in hepatocellular carcinoma by fluorescence-based TRAP method. Int Hepatol Commun 1996;6:29-35.

12 Hisatomi H, Ohmura Y, Nagao K, et al. Detection of telomerase RNA component in human liver tissues. Int Hepatol Commun 1997;6:175-8.

13 Kojima H, Yokosuka O, Imazeki F, et al. Telomerase activity and telomere length in hepatocellular carcinoma and chronic liver disease. Gastroenterology 1997;112:493-500.

14 Miura N, Horikawa I, Nishimoto A, et al. Progressive telomere shortening and telomerase reactivation during hepatocellular carcinogenesis. Cancer Genet Cytogenet 1997; 93:56-62.

15 Kyo S, Kunimi K, Uchibayashi Y, et al. Telomerase activity in human urothelial tumors. Am f Clin Pathol 1996;107: 555-60.

16 Wright WE, Shay JW, Piatyszek MA. Modifications of a telomeric repeat amplification protocol (TRAP) result in increased reliability, linearity and sensitivity. Nucleic Acids Res 1995;23:3794-5.

17 Yashima K, Piatyszek MA, Saboorian HM, et al. Telomerase activity and in situ telomerase RNA expression in malignant and non-malignant lymph nodes. $\mathcal{F}$ Clin Pathol 1997;50:110-17.

18 Yoshida K, Sugino T, Tahara $\mathrm{H}$, et al. Telomerase activity in bladder carcinoma and its implication for noninvasive diagnosis by detection of exfoliated cancer cells in urine. Cancer 1997;79:362-9.

19 Yan P, Bosman F, Benhattar J. Tissue quality is an important determinant of telomerase activity as measured by TRAP assay. Biotechniques 1998;4:660-2.

20 Niida H, Matsumoto T, Satoh H, et al. Severe growth defect in mouse cells lacking the telomerase RNA component. Nature Genet 1998;19:203-6.

21 Meyerson M, Counter CM, Eaton E, et al. hEST2, the putative human telomerase catalytic subunit gene, is up-regulated in tumor cells and during immortalization. up-regulated in tumor cell

22 Kolquist KA, Ellisen LF, Counter CM, et al. Expression of TERT in early premalignant lesions and a subset of cells in normal tissues. Nature Genet 1998;19:182-6.

23 Wellinger RJ, Ethier K, Labrecque P, et al. Evidence for a new step in telomere maintenance. Cell 1996;85:423-33.

24 Tahara H, Kuniyasu H, Yokozaki H, et al. Telomerase activity in preneoplastic and neoplastic gastric and colorectal lesions. Clin Cancer Res 1995;1:1245-51. 